\title{
Fixed-time artificial insemination using injectable progesterone: ovarian follicular dynamics and pregnancy rates of Nelore cows (Bos indicus) with and without a corpus luteum
}

\section{Inseminação artificial em tempo fixo utilizando progesterona injetável: dinâmica folicular ovariana e taxas de prenhez de vacas Nelore (Bos indicus) com e sem um corpo lúteo}

\author{
Fábio Morotti ${ }^{1}$; Jefferson Tadeu Campos ${ }^{1}$; Marcelo Marcondes Seneda ${ }^{2 *}$
}

\begin{abstract}
This study evaluated the follicular dynamics and the pregnancy rates of Nelore cows with or without a CL synchronized with FTAI employing injectable progesterone (P4). Multiparous cows ( $n=44), 45-65$ days postpartum were allocated into a $2 \times 2$ factorial. Eleven cows with and 11 without a CL received a conventional protocol of FTAI (D0/1 g P4 + 2 mg EB; D8/500 $\mu$ g cloprostenol, 300 IU eCG and $24 \mathrm{~h}$ later $1 \mathrm{mg}$ EB; D10/FTAI). Other 11 cows with and 11 without a CL received $350 \mathrm{mg}$ of injectable P4 (300 $\mathrm{mg} \mathrm{sc}$ and $50 \mathrm{mg} \mathrm{im}$ ) and $2 \mathrm{mg}$ of EB im on D0. On D6, $500 \mu \mathrm{g}$ of cloprostenol and $300 \mathrm{IU}$ of eCG were administered im. After $24 \mathrm{~h}, 1 \mathrm{mg}$ of EB was administered im and FTAI was performed on D8. The results were analyzed by ANOVA and Tukey or by Chi-square test $(\mathrm{p} \leq 0.05)$. The presence of follicles $\geq$ $5 \mathrm{~mm}$ on $\mathrm{D} 4$, follicular growth rate and CL diameter were similar between groups $(50-55 \%, 1.1-1.2 \mathrm{~mm} /$ day and 16.1-17.6mm; respectively). The diameter of the dominant follicle (DF) at FTAI and ovulatory follicle (OF) were similar between groups with CL $(10.5 \pm 1.8$ and $11.4 \pm 1.3 \mathrm{~mm}$, respectively) and without CL (10.8 \pm 2.3 and $11.1 \pm 2.2 \mathrm{~mm}$, respectively) but device was higher than injectable $(11.7 \pm 2.0$ and $11.8 \pm 1.7 v s .9 .7 \pm 1.7$ and $10.6 \pm 2.0 \mathrm{~mm}$, respectively). The ovulation and pregnancy rate were similar between groups with CL (59\% and 36\%, respectively) and without CL (77\% and 27\%, respectively) but device was higher than injectable ( $91 \%$ and $45 \%$ vs. $45.5 \%$ and $18 \%$; respectively). The ciclicity did not affect the follicular dynamics and pregnancy rate. The device showed higher diameter of the DF at FTAI, OF and ovulation and pregnancy rates. However, the injectable P4 produced similar percentages of follicles $\geq 5 \mathrm{~mm}$ on $\mathrm{D} 4$, follicular growth rate and CL diameter, raising the possibility of further investigation.
\end{abstract}

Key words: Bos indicus, ultrasonography, follicular growth, ovulation and dominant follicle

\section{Resumo}

\begin{abstract}
Este estudo avaliou a dinâmica folicular e a taxa de prenhez de vacas Nelore, com ou sem CL sincronizadas com protocolo de IATF empregando progesterona injetável (P4). Vacas multíparas ( $\mathrm{n}=44), 45-65$ dias pós-parto foram alocados em um fatorial $2 \times 2$. Onze vacas com e 11 sem CL receberam um protocolo convencional de IATF (D0/1 g P4 + 2 mg BE; D8/500 $\mu \mathrm{g}$ cloprostenol, $300 \mathrm{UI}$ eCG e $24 \mathrm{~h}$ depois $1 \mathrm{mg}$ BE; D10/IATF). Outras 11 vacas com e 11 sem CL receberam $350 \mathrm{mg}$ de P4 injetável (300 mg SC e $50 \mathrm{mg}$ IM) e $2 \mathrm{mg}$ de BE IM no D0. No D6, $500 \mu \mathrm{g}$ de cloprostenol e 300 UI de eCG foram administradas IM.
\end{abstract}

\footnotetext{
${ }^{1}$ Discentes de Doutorado do Programa de Pós-Graduação em Ciência Animal, Universidade Estadual de Londrina, UEL, Londrina, PR, Brasil.E-mail: fabiomorotti@hotmail.com; jeffersomcampos@seromtel.com.br

${ }^{2}$ Prof. Dr. do Dept ${ }^{\circ}$ de Clínicas Veterinárias, Centro de Ciências Agrárias, UEL, Londrina, PR, Brasil. E-mail: mseneda@uel.br

* Author for correspondence
} 
Após 24 h, $1 \mathrm{mg}$ de BE foi administrado IM e IATF foi realizada no D8. Os resultados foram analisados por ANOVA e teste de Tukey ou Qui-quadrado $(\mathrm{p} \leq 0,05)$. A presença de folículos $\geq 5 \mathrm{~mm}$ no D4, a taxa de crescimento folicular e o diâmetro do CL foram semelhantes entre os grupos $(50-55 \%, 1,1-1,2 \mathrm{~mm} /$ dia e 16,1-17,6mm, respectivamente). O diâmetro do folículo dominante (FD) na IATF e do folículo ovulatório (FO) foram semelhantes entre os grupos com CL (10,5 $\pm 1,8$ e 11,4 $\pm 1,3 \mathrm{~mm}$, respectivamente) e sem CL (10,8 $\pm 2,3$ e 11,1 $\pm 2,2 \mathrm{~mm}$, respectivamente), mas foi maior no grupo dispositivo comparado

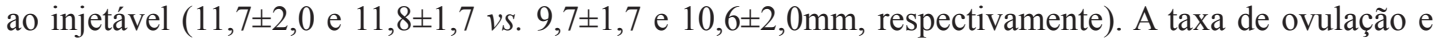
de prenhez foram semelhantes entre os grupos com CL (59\% e 36\%, respectivamente) e sem CL (77\% e $27 \%$, respectivamente), mas foi mais elevada no grupo dispositivo comparado com o injetável (91\% e $45 \%$ vs. $45,5 \%$ e $18 \%$, respectivamente). A ciclicidade não interferiu na dinâmica folicular e na taxa de gestação. O dispositivo apresentou maior diâmetro do FD na IATF, do FO e das taxas de ovulação e prenhez. No entanto, a P4 injetável produziu percentagens semelhantes de folículos $\geq 5 \mathrm{~mm}$ no D4, de taxa de crescimento folicular e diâmetro do CL, levantando a possibilidade de novas investigações.

Palavras-chave: Bos indicus, ultrassonografia, crescimento folicular, ovulação e folículo dominante

\section{Introduction}

Brazil has a privileged position in the field of artificial insemination (AI) of cattle, having the largest commercial herd (200 million cattle) and the largest market for fixed-time artificial insemination (FTAI) in the world. Recently, the use of AI showed impressive growth and this progress was mainly due to the increased use of FTAI. In 2002, approximately 100,000 cows were inseminated using FTAI and in 2012 , this number was more than 6.5 million.

Progesterone (P4) or progestin is the principal hormonal basis of estrus synchronization in most FTAI programs for cattle. This hormone can be used in the form of an intravaginal device, an ear implant or an oral formulation (BARUSELLI et al., 2004a).

During treatment using the intravaginal device (5-10 days), P4 exerts negative feedback on estradiol and inhibits the LH surge, thus preventing estrus and the ovulation of the dominant follicle (DF) (BARUSELLI et al., 2004a). When associated with estrogen on D0, P4 promotes the regression of the DF and the synchronized emergence of a new follicular wave. After this treatment, PGF2 $\alpha$ can be administered to promote estrus synchronization, and estradiol, GnRH or LH can be administered to induce ovulation synchronization (BÓ et al., 2002).

Currently, there are many protocols of estradiol/ P4-based FTAI that efficiently control the estrus and ovulation of cattle (SÁ FILHO et al., 2010;
SALES et al., 2012) but to improve the reproductive management, minimize service and reduce costs, it is necessary to remain at the forefront of advances in reproductive biotechnology. The use of an injectable P4 source to control the estrous cycle would more practical the current FTAI programs and other reproductive biotechnologies because one of the major advantages of injectable P4 is the labor reduction when FTAI is used on large scale, due mainly the facility of application route.

The effects of injectable P4 on controlling the estrous cycle of cattle (ULBERG; LINDLEY, 1960; FIKE et al., 1999) and in FTAI protocols (Morotti et al., unpublished) has been scarcely studied. Therefore, the aim of this study was to evaluate ovarian follicular dynamics and the pregnancy rates of Nelore cows (Bos indicus), with or without $\mathrm{CL}$, subjected to FTAI using injectable P4 or an intravaginal $\mathrm{P} 4$ device.

\section{Materials and Methods}

Site, animals and feed management

The experiment was conducted during the breeding season (November to March) in South America, latitude $23^{\circ} 24^{\prime} 23^{\prime \prime}$ and longitude $57^{\circ} 26^{\prime} 4^{\prime \prime}$. The climate in this region is tropical, with an average temperature of $24^{\circ} \mathrm{C}$, and a rainy season from November to January. 
Forty-four, multiparous Nelore cows (Bos indicus) between 72 and 84 months of age and at 45 to 65 days postpartum were used in this study. The animals had body condition scores (BCSs) of between 2.5 and $3.5(2.8 \pm 0.1)$ on a scale of 0 to 5 (AYRES et al., 2009) and an average weight of $410.3 \pm 47.5 \mathrm{~kg}$.

During the experimental period, the cows were maintained by continuous grazing of Brachiaria brizantha and Brachiaria humindicula. They were given access to mineralized salt and water ad libitum.

\section{Animal selection}

The cows were previously selected according to their ovarian activity. Evaluations by palpation and transrectal ultrasonography, using an Aloka model SSD-500 ultrasound instrument equipped with a $5 \mathrm{MHz}$ linear transducer (Aloka, Tokyo, Japan), were performed to select 22 cows with a CL and 22 cows without a CL and with large follicles $<8 \mathrm{~mm}$ in diameter (BARUSELLI et al., 2004a).

\section{Experimental design and treatments}

The selected animals were allocated into a $2 \times 2$ factorial matrix. Eleven cows with and 11 cows without a CL were subjected to conventional FTAI using an intravaginal device containing $1 \mathrm{~g}$ of $\mathrm{P} 4$ (DIB $\AA$, Syntex, Buenos Aires, Argentina) and an intramuscular (im) application of $2 \mathrm{mg}$ estradiol benzoate (EB) (Syntex ${ }^{\circledR}$, Syntex, Buenos Aires, Argentina) on D0. Eight days later (D8), the device was removed and $500 \mu \mathrm{g}$ of cloprostenol (DL Cyclase ${ }^{\circledR}$, Syntex, Buenos Aires, Argentina) and 300 IU of equine chorionic gonadotropin (eCG); (Novormon ${ }^{\circledR}$, Syntex, Buenos Aires, Argentina) were administered im. On D9, 1 mg of EB (Syntex ${ }^{\circledR}$, Syntex, Buenos Aires, Argentina) was administered im and FTAI performed on D10, $48 \mathrm{~h}$ after device removal.
The other cows (11 with and 11 without CL) received $350 \mathrm{mg}$ of injectable P4 (300 mg subcutaneously ${ }^{3}$ and $50 \mathrm{mg} \mathrm{im}^{4}$ ) and $2 \mathrm{mg}$ of EB (im) on D0. Six days later (D6), $500 \mu \mathrm{g}$ of cloprostenol and $300 \mathrm{IU}$ of eCG were administered im. On D7, $1 \mathrm{mg}$ of EB im was administered, and FTAI was performed on D8, $24 \mathrm{~h}$ after the ovulation inductor. This timing was established based on the results of previous studies (Unpublished data).

\section{Follicular dynamics}

The follicular dynamics were evaluated using transvaginal ultrasonography with an Aloka ${ }^{\circledR}$ SSD500 ultrasound system equipped with a $7.5 \mathrm{MHz}$ micro convex transducer (Aloka, Tokyo, Japan) and coupled to a follicular aspiration guide.

Evaluations were performed on D0, D4 and every $24 \mathrm{~h}$ thereafter until FTAI. Ovulation was monitored every $12 \mathrm{~h}$ after insemination, and the CL was assessed 12 days after FTAI. All of the data were obtained for both ovaries and recorded individually for further monitoring.

For each evaluation, both ovaries were ultrasonically scanned, and the follicles $\geq 5 \mathrm{~mm}$ were identified and measured using the ultrasonography package. The average of two cross-sectional linear measurements of the follicular antrum was calculated (GINTHER; KNOPF; KASTELIC, 1989).

Behavioral estrus was observed twice daily for $1 \mathrm{~h}$ from 6:00 a.m. to 7:00 p.m. The observations began at the time of cloprostenol administration (D6 for injectable P4 and D8 for the intravaginal device) and ended $60 \mathrm{~h}$ afterward. Estrus was considered to have occurred when the cow stood to be mounted by another cow (standing estrus).

The DF was defined as the follicle that grew to at least $>8 \mathrm{~mm}$ and exceeded the diameter of

\footnotetext{
${ }^{3}$ Natural progesterone in vehicle sesame and peanut oil (slow absorption).

${ }^{4}$ Natural progesterone in vehicle sesame and peanut oil (fast absorption).
} 
all other follicles (FIGUEIREDO et al., 1997). Ovulation was detected by the absence of the previously identified DF and confirmed by the later presence of a CL in the same ovary. On the 12th day after FTAI, the CL was measured in the ovary that previously contained the DF (GINTHER; KNOPF; KASTELIC, 1989). The pregnancy rate was determined by ultrasonography 35 days after the FTAI.

\section{Parameters evaluated and statistical analyses}

The animals were evaluated for the presence of follicles $\geq 5 \mathrm{~mm}$ on D4 $(\%, \mathrm{~mm})$, the average rate of follicular growth (mm/day), the rate of behavioral estrus $(\%)$, the diameter of the DF at FTAI (mm), the diameter of the ovulatory follicle $(\mathrm{OF})(\mathrm{mm})$, the ovulation rate $(\%)$, the diameter of the CL $(\mathrm{mm})$ and the pregnancy rate $(\%)$

Parametric data were assessed using an analysis of variance (ANOVA). If the difference between the groups was significant, the data were examined using Tukey test. Frequency data and dichotomous variables were analyzed using the Chi-squared test.

All of the data were analyzed using the Statistical Software MNITAB16 program. The significance level for rejecting the $\mathrm{H} 0$ (null hypothesis) was $5 \%$; namely, a level of significance $\leq 0.05$ was considered to indicate an effect of the categorical variables and their interactions. The parametric data are presented as the mean values $+/$ - one standard deviation $(\mathrm{M} \pm \mathrm{SD})$.

\section{Results and Discussion}

To our knowledge, this is the first study evaluating the use of injectable P4 (with a single parenteral application) for FTAI of cattle. We described the protocol used and the first results concerning the follicular dynamics in Nelore cows with and without CL. This study is expected to serve as the basis for the use of injectable P4, considering the lack of information about this product.

The percent of follicles $\geq 5 \mathrm{~mm}$ on $\mathrm{D} 4$, follicular growth, estrous behavior rate and diameter of the CL were similar for the cows that were synchronized using an intravaginal device or injectable P4. However, the animals that received the injectable $\mathrm{P} 4$ exhibited a DF with a smaller diameter at FTAI, an OF with a smaller diameter and lower ovulation and pregnancy rates (Table 1). 


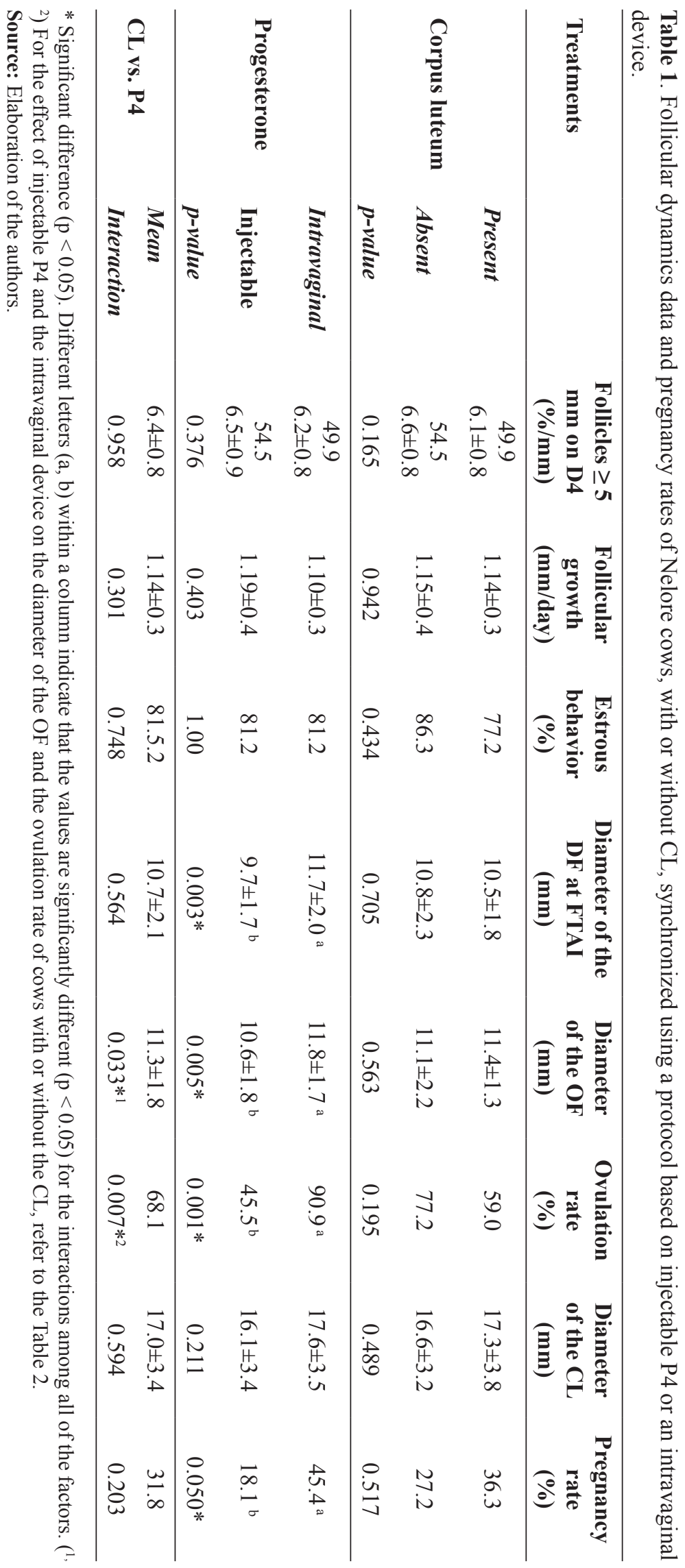


The average rate of follicular growth in our study was similar in the groups that received the intravaginal device $(1.10 \pm 0.3 \mathrm{~mm} / \mathrm{day})$ or the injectable P4 $(1.19 \pm 0.4 \mathrm{~mm} /$ day; $\mathrm{p}=0.403)$. No interaction was observed between the ovarian activity and the form of P4 used; namely, the rates of follicular growth in the cows treated with injectable P4 or with the intravaginal device, regardless of the presence or absence of CL, were similar. These rates are similar to those obtained by Coutinho et al. (2007) (1.0 $\pm 0.1 \mathrm{~mm} /$ day) in multiparous Bos indicus cows and higher than those observed by Callejas et al. (2006) in Bos taurus cows treated with the following daily doses of P4: $600 \mathrm{mg}(0.1 \pm 0.1 \mathrm{~mm} /$ day), $400 \mathrm{mg}(0.6 \pm 0.2 \mathrm{~mm} /$ day $)$ or $200 \mathrm{mg}(0.5 \pm 0.1$ $\mathrm{mm} /$ day). In this study, the dose of injectable P4 (350 mg P4 only on D0) chosen induced follicular growth rates similar to those induced using the intravaginal device.

The cows synchronized using the intravaginal device showed a larger diameter of the DF at FTAI $(11.7 \pm 2.0 \mathrm{~mm})$ compared with those receiving injectable P4 $(9.7 \pm 1.7 \mathrm{~mm}$; $\mathrm{p}=0.003)$. However, no interaction between the ovarian activity and the form of P4 used was observed. In Bos indicus beef cows synchronized using an estradiol/P4based FTAI protocol, Sá Filho et al. (2010) found an average diameter of $11.1 \pm 0.3 \mathrm{~mm}$ at FTAI. Siqueira et al. (2009) also reported similar data in
Bos taurus beef cows, which displayed follicular diameters of $10.5 \pm 0.1,10.7 \pm 0.1$ and $10.6 \pm 0.4$ $\mathrm{mm}$ when synchronized using an intravaginal device containing $250 \mathrm{mg}$ of medroxyprogesterone acetate, an intravaginal device containing $250 \mathrm{mg}$ of medroxyprogesterone acetate plus $100 \mathrm{mg}$ of P4 given im or an intravaginal device containing $1 \mathrm{~g}$ of $\mathrm{P} 4$, respectively.

The cows synchronized using the intravaginal device displayed a larger diameter of the $\mathrm{OF}$ $(11.8 \pm 1.7 \mathrm{~mm})$ than did the cows that received injectable P4 $(10.6 \pm 1.8 \mathrm{~mm} ; \mathrm{p}=0.005)$. For this variable, the association of the factors of the intravaginal device and the absence of the CL provided a larger diameter of the OF $(12.4 \pm 1.3$ $\mathrm{mm}$ ) than did the factors of the injectable P4 and the absence of the CL $(10 \pm 2.0 \mathrm{~mm} ; \mathrm{p}=0.033)$. In contrast, the presence of the CL in cows treated with injectable P4 $(12.2 \pm 1.4 \mathrm{~mm})$ yielded results similar to those that received the intravaginal device (12.1 $\pm 1.2 \mathrm{~mm} ; \mathrm{p}>0.05)$; (Table 2). In postpartum beef cows, the OF size can vary widely and may be $<11 \mathrm{~mm}$ or $>16 \mathrm{~mm}$ [13]. The data obtained in the present study (intravaginal and injectable groups) showed smaller diameters of the OF than were observed by Sales et al. (2012) in Nelore cows undergoing FTAI, which were $13.1 \pm 0.4$ and $13.9 \pm 0.4 \mathrm{~mm}$ for ovulation induced by $\mathrm{EB}$ or $\mathrm{EC}$, respectively.

Table 2. Average diameter of the ovulatory follicle and average ovulation rate of Nelore cows with or without CL, using a protocol based on injectable P4 or an intravaginal device.

\begin{tabular}{lcc}
\hline Progesterone vs. Corpus luteum & Ovulatory follicle $\left.^{\mathbf{1}} \mathbf{( m m}\right)$ & Ovulation rate $^{\mathbf{2}} \mathbf{( \% )}$ \\
\hline Injectable P4 with CL & $12.2 \pm 1.4^{\mathrm{a}}$ & $36.3^{\mathrm{c}}$ \\
Injectable P4 without CL & $10 \pm 2.0^{\mathrm{b}}$ & $54.5^{\mathrm{bc}}$ \\
Intravaginal device with CL & $12.1 \pm 1.2^{\mathrm{a}}$ & $81.8^{\mathrm{ab}}$ \\
Intravaginal device without CL & $12.4 \pm 1.3^{\mathrm{a}}$ & $100^{\mathrm{a}}$ \\
\hline
\end{tabular}

Different letters $(a, b, c)$ within a column indicate that the values are significantly different $(\mathrm{p}<0.05)$.

Source: Elaboration of the authors.

The ovulation rate was lower in the animals in those synchronized using the intravaginal treated with injectable P4 $(45.5 \%, 10 / 22)$ than device $(90.9 \%, 20 / 22 ; p=0.001)$. Furthermore, an 
interaction between ovarian activity and $\mathrm{P} 4$ use was observed $(p=0.007)$. Cows without a CL that received an intravaginal device exhibited a better ovulation rate $(100 \%, 11 / 11)$ than those treated with injectable P4, whether without a CL $(54.5 \%, 6 / 11)$ or with a CL $(36.3 \%, 4 / 11)$. However, cows without a CL that were synchronized using injectable P4 had an ovulation rate similar to that of the cows with a $\mathrm{CL}$ that were treated using the intravaginal device $(81.8 \%, 9 / 11)$ (Table 2). Most of the cows ovulated within $12-24 \mathrm{~h}$ of FTAI ( $90 \%$ in the injectable P4 group and $95 \%$ in the intravaginal device group). In Nelore cows that were synchronized using an estradiol/P4-based FTAI protocol, Sales et al. (2012) observed a lower EB-induced ovulation rate with the use of the intravaginal device of $77.8 \%$ of the cows (21/27). The ovulation rate of the injectable P4 group was lower than that observed in the control group or those reported in the literature.

Generally, estradiol/P4-based FTAI protocols are highly efficient in synchronizing a wave of follicular growth and ovulation in Bos indicus cows (SÁ FILHO et al., 2011; SALES et al., 2012). In the present study, only one cow with an intravaginal device showed no follicular recruitment or growth, whereas $95 \%$ of the cows responded to the protocol and $90.9 \%$ ovulated. All of the cows given the injectable P4 demonstrated follicular recruitment and growth, with follicles $>7 \mathrm{~mm}$ in diameter at FTAI; however, only $45.4 \%$ of this group ovulated.

Other than the individual characteristics of $\mathrm{P} 4$ metabolism, it is possible that the BCS also had some influence (RODRIGUES et al., 2011), resulting in variable levels of LH and affecting ovulation. In the present study, the ovulation rate was higher in cows with a BCS close to 3 .

In the animals that received the injectable P4, ultrasonography performed until $48 \mathrm{~h}$ after FTAI revealed that some of the non-ovulatory cows continued to experience DF growth, followed by a reduction in the DF diameter without achieving ovulation. A longer period of DF growth might increase the diameter of the OF and the ovulation rate. Other ovulation inducers, such as $\mathrm{GnRH}$ and LH, could also be used. A study of the plasma profile of associated with injectable P4 may yield important information to better direct its use in FTAI protocols.

An interesting result of this study is that the CL size was similar in the groups, regardless of their cyclicity (CL present: $17.3 \pm 3.8 \mathrm{~mm}$ and CL absent: $16.6 \pm 3.2 \mathrm{~mm} ; \mathrm{p}=0.489$ ) or the form of $\mathrm{P} 4$ utilized (intravaginal device: $17.6 \pm 3.5 \mathrm{~mm}$ and injectable P4: $16.1 \pm 3.4 \mathrm{~mm} ; \mathrm{p}=0.211$ ). This result suggests the possibility of using injectable $\mathrm{P} 4$ in the protocol for fixed-timed embryo transfer research.

In our study, the small number of animals $(n=44)$ is a limitation in evaluating the pregnancy rate; nevertheless, we considered that it was important to provide these data due lack of information of injectable P4. The pregnancy rate was higher in the cows synchronized using the intravaginal device $(45.4 \%, 10 / 22)$ compared than those treated with injectable P4 (18.1\%, 4/22; $\mathrm{p}=0.05)$. A similar rate was found in beef cows treated with $50 \mathrm{mg}$ of P4 daily (for 14 days), followed $72 \mathrm{~h}$ later by $0.5 \mathrm{mg}$ of EB, which had a $15 \%(4 / 26)$ pregnancy rate. In the animals that received $25 \mathrm{mg}$ of $\mathrm{P} 4$ and $1 \mathrm{mg}$ of EB, the pregnancy rate was 38\% (16/42) (ULBERG; LINDLEY, 1960). The lower fertility observed in our study was due to the lower ovulation rate of the animals that received the injectable P4. Despite the effect of $\mathrm{P} 4$ on the pregnancy rate, an interaction between ovarian activity and P4 use was not observed.

The pregnancy rates of the intravaginal device groups were lower than those found by Bader et al. (2005) and Schafer et al. (2007), but similar to those found by Colazo et al. (2004). In a study of Nelore cows synchronized using an intravaginal P4 device, Silveira et al. (2012) reported pregnancy rates of $53 \%$. In contrast, Baruselli et al. (2004b) obtained a $43 \%$ rate and reported that these variations are attributable to different types of 
property management, thereby allowing diversity in the pregnancy rate from 40 to $60 \%$.

In conclusion, Nelore cows treated with an intravaginal device and subjected to a FTAI protocol exhibited DFs with a larger diameter at FTAI, OFs of a larger diameter, and higher ovulation and pregnancy rates. However, the cows that received injectable $\mathrm{P} 4$ had a similar percentage of follicles $\geq 5 \mathrm{~mm}$ on $\mathrm{D} 4$, rate of follicular growth, rate of behavioral estrus and a CL diameter, raising the possibility of further investigation. It is possible that the injectable P4 is not completely metabolized during the treatment for FTAI, resulting in variable levels of LH and blocking ovulation.

\section{Acknowledgements}

We are grateful to Dr. Renato Castanho Francisco for supporting in this study, to the staff of Santa Edwiges Farm (Yby Yaú, Paraguay) for allowing the use of their animals and facilities for this study and to the Graduate Program in Animal Science of the State University of Londrina, Londrina, Parana, Brazil. This research was supported by Santa Edwiges Farm and the Coordination for the Improvement of Higher Level or Education Personnel (CAPES).

\section{References}

AYRES, H.; FERREIRA, R. M.; TORRES-JÚNIOR, J. R. S.; DEMÉTRIO, C. G. B.; LIMA, C. G.; BARUSELLI, P. S. Validation of body condition score as a predictor of subcutaneous fat in Nelore (Bos indicus) cows. Livestock Science, Philadelphia, v. 123, n. 2-3, p. 175-179, 2009.

BADER, J. F.; KOJIMA, F. M.; SCHAFER, D. J.; STEGNER, J. E.; ELLERSIECK, M. R.; SMITH, M. F.; PATTERSON, D. J. A comparison of progestin-based protocols to synchronize ovulation and facilitate fixedtime artificial insemination in postpartum beef cows. Journal of Animal Science, Champaign, v. 83, n. 1, p. 136-143, 2005.

BARUSELLI, P. S.; MADUREIRA, E. H.; MARQUES, M. O.; RODRIGUES, C. A.; NASSER, L. F.; SILVA, R.
C. P.; REIS, E. L.; SÁ FILHO, M. F. Efeito do tratamento com eCG na taxa de concepção de vacas Nelore com diferentes escores de condição corporal inseminadas em tempo fixo (análise retrospectiva). Acta Scientiae Veterinariae, Porto Alegre, v. 32, p. 228, 2004a.

BARUSELLI, P. S.; REIS, E. L.; MARQUES, M. O.; NASSER, L. F.; BÓ, G. A. The use of hormonal treatments to improve reproductive performance of anestrous beef cattle in tropical climates. Animal Reproduction Science, Amsterdam, v. 82-83, p. 479-486, 2004 b.

BÓ, G. A.; BARUSELLI, P. S.; MORENO, D.; CUTAIA, L.; CACCIA, M.; TRIBULO, R.; TRIBULO, H.; MAPLETOFT, R.J. The control of follicular wave development for self-appointed embryo transfer programs in cattle. Theriogenology, Stoneham, v. 57, n. 1, p. 53-72, 2002.

CALLEJAS, S. S.; ALBERIO, R.; CABODEVILA, J.; DULOUT, A. F.; ALLER, J.; CATALANO, R.; TERUEL, M. Influence of different doses of progesterone treatments on ovarian follicle status in beef cows. Animal Reproduction Science, Amsterdam, v. 91, n. 3-4, p. 191200, 2006.

COLAZO, M. G.; KASTELIC, J. P.; WHITTAKER, P. R.; GAVAGA, Q. A.; WILDE, R.; MAPLETOFT, R. J. Fertility in beef cattle given a new or previously used CIDR insert and estradiol, with or without progesterone. Animal Reproduction Science, Amsterdam, v. 81, n. 1-2, p. 25-34, 2004.

COUTINHO, G. T. R. M.; VIANA, J. H. M.; SÁ, W. F.; CAMARGO, L. S.; FERREIRA, A. M.; PALHÃO, P. M.; NOGUEIRA, L. A. G. Avaliação ultra-sonográfica da dinâmica folicular e lútea em vacas da raça Guzerá. Arquivo Brasileiro de Medicina Veterinária e Zootecnia, Belo Horizonte, v. 59, n. 5, p. 1089-1096, 2007.

FIGUEIREDO, R. A.; BARROS, C. M.; PINHEIRO, O. L.; SOLER, J. M. P. Ovarian follicular dynamics in Nelore breed (Bos indicus) cattle. Theriogenology, Stoneham, v. 47, n. 8, p. 1489-1505, 1997.

FIKE, K. E.; WEHRMAN, M. E.; LINDSEY, B. R.; BERGFELD, G.; MELVIN, E. J.; QUINTAL, J. A.; ZANELLA, E. L.; KOJIMA, F. N.; KINDER, J. E. Estrus synchronization of beef cattle with a combination of melengestrol acetate and an injection of progesterone and $17 \beta$-estradiol. Journal of Animal Science, Champaign, v. 77, p. 715-723, 1999.

GINTHER, O. J.; KNOPF, L.; KASTELIC, J. P. Temporal association among ovarian events in cattle during oestrus cycles with two and three follicular waves. Journal of Reproduction and Fertility, Cambridge, v. 87, p. 223230, 1989. 
RODRIGUES, R. O.; TREVISANUTO, C.; COOKE, R. F.; VASCONCELOS, J. L. M. Effects of body weight loss on serum progesterone concentrations of non-lactating dairy cows. Theriogenology, Stoneham, v. 75, n. 1, p. 131-137, 2011.

SÁ FILHO, M. F.; CRESPILHO, A. M.; SANTOS, J. E. P.; PERRY, G. A.; BARUSELLI, P. S. Ovarian follicle diameter at timed insemination and estrus response influences the likelihood of ovulation and pregnancy after synchronization with progesterone or progestinbased protocols in suckled Bos indicus cows. Journal of Animal Science, Champaign, v. 120, n. 1, p. 23-30, 2010.

SÁ FILHO, M. F.; SANTOS, J. E.; FERREIRA, R. M.; SALES, J. N.; BARUSELLI, P. S. Importance of estrus on pregnancy per insemination in suckled Bos indicus cows submitted to estradiol/progesterone based timed insemination protocols. Theriogenology, Stoneham, v.76, n. 3, p. 455-463, 2011.

SALES, J. N. S.; CARVALHO, J. B. P.; CREPALDI, G. A.; CIPRIANO, R. S.; JACOMINI, J. O.; MAIO, J. R. G.; SOUZA, J. C.; NOGUEIRA, G. P.; BARUSELLI, P. S. Effects of two estradiol esters (benzoate and cypionate) on the induction of synchronized ovulations in Bos indicus cows submitted to a timed artificial insemination protocol. Theriogenology, Stoneham, v. 78, n. 3, p. 510516, 2012.
SCHAFER, D. J.; BADER, J. F.; MEYER, J. P.; HADEN, J. K.; ELLERSIECK, M. R.; LUCY, M. C.; SMITH, M. F.; PATTERSON, D. J. Comparison of progestin-based protocols to synchronize estrus and ovulation before fixed-time artificial insemination in postpartum beef cows. Journal of Animal Science, Champaign, v. 85, n. 8, p. 1940-1945, 2007.

SILVEIRA, E. C.; BORTOLLOTI, L. A.; MOROTTI, F.; SENEDA, M. M. Plasmatic level of progesterone and pregnancy rate in Nellore bovine synchronized with new intravaginal progesterone device (Biocowgest $\AA$ ). Revista Acadêmica Ciências Agrárias e Ambientais, Curitiba, v. 10, p. 73-79, 2012.

SIQUEIRA, L. C.; OLIVEIRA, J. F.; ROVANI, M. T.; FERREIRA, R.; BORGES, L. F.; GONÇALVES, P. B. Effects of estradiol and progestins on follicular regression before, during, and after follicular deviation in postpartum beef cows. Theriogenology, Stoneham, v. 71, n. 4, p. 614-619, 2009.

ULBERG, L. C.; LINDLEY, C. E. Use of progesterone and estrogen in the control of reproductive activities in beef cattle. Journal of Animal Science, Champaign, v. 19, n. 4, p. 1132-1142, 1960. 
